\title{
Effects of Different Types of Feed on the Growth and Survival Rate of Betta splendens
}

\author{
Resti Ayu NengTias ${ }^{1}$, Ni Luh Watiniasih ${ }^{2}$, and Ayu Putu Wiweka Krisna Dewi ${ }^{3}$ \\ ${ }^{1,2,3}$ Department of Aquatic Resources Management, Faculty of Marine and Fisheries, Udayana University \\ Jl. Kampus Unud Bukit Jimbaran, Kuta Selatan, Badung, Bali \\ *Corresponding author: restiayu717@gmail.com
}

\begin{abstract}
Betta fish (Betta splendens) are freshwater ornamental fish that are very popular among because it's beautiful colors and unique behavior. This study aims to determine the growth by measuring weight and length as well as the survival rate of betta fish seeds. The fish providing by different types of food and this research was conducted in door at Tulungagung, East Java, Indonesia. The study was experimentally designed with completely randomized design consisting of 3 treatments and 4 replications. The treatment A was fed with Tubifex sp., treatment B with artificial food (pellets), and treatment C was consisted of a combination of Tubifex sp., and artificial food. The tested fish were 30 days old with a stocking density of 5 ind./plastic bucket, where feeding was done ad-libitum. The study was conducted for 42 days. The parameters measured in this study were the growth in absolute weight and absolute length and its survival rate. Observations were analyzed using One Way Analysis of Variance (ANOVA) and further tests were carried out using the Duncan test. The results show that different feeding strategies had a significant effect on the growth of absolute weight and absolute length, and had no significant effect on the survival rate of betta fish. Water quality parameters measured include an average temperature was valued at $25.01^{\circ} \mathrm{C}-25.87^{\circ} \mathrm{C}$, while the average $\mathrm{pH}$ was 8.42-8.47, and average dissolved oxygen (DO) was 4.13-4.17 mg/L.
\end{abstract}

Keywords: betta fish; combination of feed; growth; survival rate

\section{INTRODUCTION}

Betta splendens is a freshwater ornamental fish. This fsh has a beautiful color, unique behavior, and is easy to maintain in an oxygen-poor environment so that it is liked by many peaole [1]. Betta fish cultivation is currently an alternative in increasing family income during the Covid19 (Corona Viruses-19) pandemic, Yusuf [2] stated that the development of betta fish cultivation in the community in the hatchery is still not good enough. In the hatchery, betta fish was found relatively slow in growth. The slow growth factor is thought to be influenced by feedings, so that feeding strategy should be considered in supporting the success of betta fish cultivation.

Good food that has a complete nutritional composition, such as it contains balanced of protein, carbohydrates, fats, and minerals. There are two types of fish food that are available, namely natural and artificial food [3]. Increasing consumer demand for natural food causes shorten supply of natural food for the freshwater ornamental fish industry due to limitations in nature. Another alternative that can be taken in fish farming is to provide feed from different sources, namely combination of natural and artificial food $[4,5]$. There is no such study has been found for betta fish, so it is necessary to study the effect of different types of food, namely natural, artificial food types, and the combinations of natural and artificial food, so that it can be found the best type of food for the growth and survival rate of seeds of the betta fish (B. splendens).

\section{METODE}

Experimental Design

The experimental with a completely randomized design was used which consisted of three treatments, those were: treatment $\mathrm{A}$ where the fish was fed with natural feeding that was Tubifex sp., for 6 weeks, treatment B was fed with artificial food for 6 weeks, and treatment $C$ was fed with the combination of natural food which was given for the first 3 weeks, then continued with artificial food for until the end of the study. Each treatment was repeated four times.

\section{Fish Sources and Maintenance}

Betta splendens were obtained from ornamental fish farmers in Kediri. The fish used for this experiment was 30 day old betta fish with a stocking density of 5 fish for each plastic bucket and filled with 4.5 liters of water. Food was given ad-libitum twice a day. 


\section{Location and Research period}

The research was carried out for 42 days, from $23^{\text {th }}$ of December 2020 to $3^{\text {rd }}$ of February 2021. The research was carried in door at Tulungagung, East Java, Indonesia.

\section{Research Parameters}

The parameters measured in this study were the absolute weight growth, absolute length growht, and survival rate of the fish. The water quality was measured as supporting parameters included temperature, DO, and $\mathrm{pH}$. The formulas used in the study for calculation of the parameter are following Effendie (1997) with slight modification [6]:

\section{Absolute Weight Growth}

Absolute weight growth was calculated using formula:

$$
\mathrm{W}=\mathrm{Wt}-\mathrm{Wo}_{\mathrm{O}}
$$

Noted: W: Absolute weight gain (g), Wt: Weight of fish at the end of study $(\mathrm{g})$, Wo: Initial fish weight $(\mathrm{g})$

\section{Absolute Lenght Growth}

Absolute length growth was calculated using formula:

$$
\mathrm{Lm}=\mathrm{Lt}-\mathrm{Lo}
$$

Noted: $\mathrm{Lm}=$ absolute length growth $(\mathrm{cm}), \mathrm{Lt}=$ the length of the fish at the end of the study $(\mathrm{cm})$, Lo = the length of the fish at the beginning of the study $(\mathrm{cm})$

Survival Rate (SR)

Survival rate calculated was using formula:

$$
\mathrm{SR}=\frac{N t}{N 0} \times 100 \%
$$

Noted: $\mathrm{SR}=$ Fish survival $(\%), \mathrm{Nt}=$ Number of fish at the end of the study (tail), No $=$ Number of fish at the beginning of the study (tail)

\section{Data analysis}

Data analysis using ANOVA (analysis of variance) variance at a $95 \%$ confidence level with an error range of 5\% through a computer program SPSS 24.0 (Statistical Product and Service Solutions). If the results were obtained that were significantly different in weight and length growth and the viability of betta fish seeds, then the Duncan test was continued at the $95 \%$ confidence level.

\section{RESULT AND DISCUSSION}

The Absolute Weight of Betta Fish (B. splendens) Seeds

The absolute weight growth of betta fish (B. splendens) seeds ranged from 0.10 to $0.52 \mathrm{~g}$. The highest value was found in treatment $\mathrm{A}$ with the verage of $0.52 \mathrm{~g}$, then in treatment $\mathrm{C}$ with the average of $0.36 \mathrm{gr}$, and the lowest absolute weight value was measured in treatment $B$ with an average of $0.10 \mathrm{~g}$. The statistical test showed that there are significant differences among treatments $(\mathrm{P}<0.05)$, which means that all treatments have significant effect on the absolute growth weight of Betta fish seeds (Figure 1).

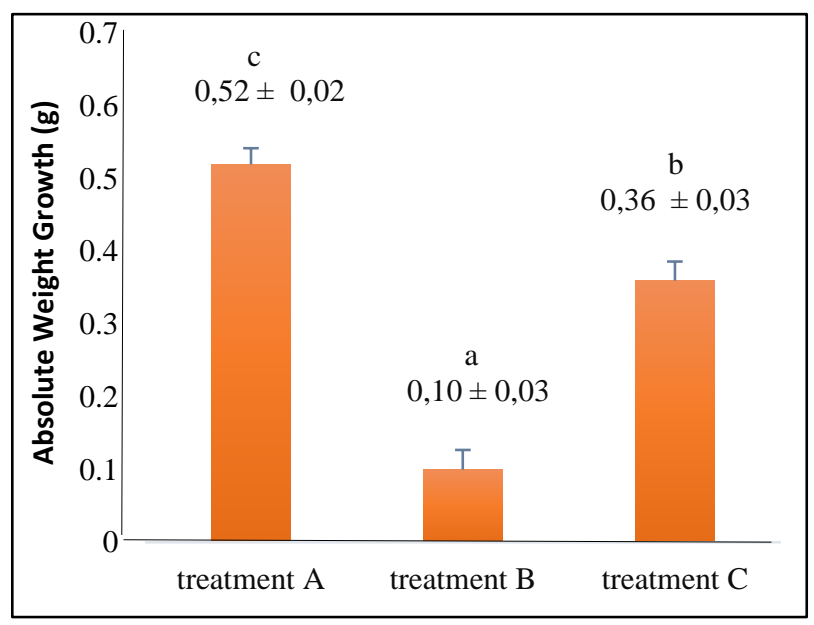

Figure. 1 Absolute Weight Growth of B. splendens

Noted: Different superscip letters in the image indicated that the treatment is significantly different $(\mathrm{P}<0,05)$ compared to other treatments.

The highest absolute weight were found in treatment $\mathrm{A}$ (fed with silkworms for 6 weeks). Silkworms (Tubifex sp.,) provide a better nutrition needed for the growth of betta fish, which was found that $57 \%$ of its contain protein. In addition, silkworms are a natural food for betta fish seeds, easier to digest, where the digestive system of the fish seeds is still not fully grown. [7] Furthermore, they said that the silkworms can attract the fish to feed on and due to the silkworm is small in size, so easy for the fish seeds to consume.

Feeding pellets for 6 weeks in treatment B experienced the smallest increase compared to treatments $\mathrm{A}$ and $\mathrm{C}$. This is presumably because artificial feed or pellets contain substances that are lower digestibility compared to silk worms, so that growth is slower than the other two treatments. This is in accordance with Trisnawati et al., [8] that giving artificial feed (pellets) to african catfish seeds resulted in the lowest growth and it is suspected that ingested artificial food produced less energy than natural feed, which resulted in a smaller increase in growth compared to natural feed.

The combination food in treatment $\mathrm{C}$ (silkworms for 3 weeks and pellet from week four until the end of the treatment) resulted in a smaller absolute weight than in treatment A, but higher than in treatment B. The first week until the third week the growth was increasing $(0,30 \mathrm{~g})$, then decreased/steady while the pellet was given in the fourth week until the end of the treatments $(0.06 \mathrm{~g})$. These results indicate that pellets cannot replace silkworms to obtain the absolute weight in raising betta fish seeds until the age of 10 weeks. In the seed phase, betta fish should be given silkworms compared to pellet feed because silkworms are a natural food that can produce optimal fish 
seed growth. This is following the opinion of Kasegar et al., [9] which states that silkworms are a natural food that is suitable for feeding larvae and fish seeds because there is high nutritional content, the size of the feed is following the fish's mouth opening, and is easily digested by the fish's body.

Growth of Absolute Lenght of Betta Fish Seeds ( $B$. splendens)

Based on the observations, it was found that the absolute length growth in the betta fish (B. splendens) ranged from 0.57 to $1.33 \mathrm{~cm}$. The highest value was obtained in treatment $\mathrm{A}$ with an average of $1.33 \mathrm{~cm}$, then the result was in treatment $\mathrm{C}$ with an average of $1.25 \mathrm{~cm}$, and the lowest absolute length value was obtained in treatment B with an average of $0.57 \mathrm{~cm}$. The results of the One-Way ANOVA statistical test showed that the significance value was smaller than 0.05 ( $\mathrm{P}<0.05)$, which means that all treatments had a significantly different effect on the absolute length growth of betta fish (B. splendens) seeds.

The follow-up test used the Duncan test which showed that treatment B was significantly different from treatment $A$ and $C$ while treatment $B$ was not significantly different from treatment $\mathrm{A}$. The results of the Duncan test performed can be seen in Figure 2.

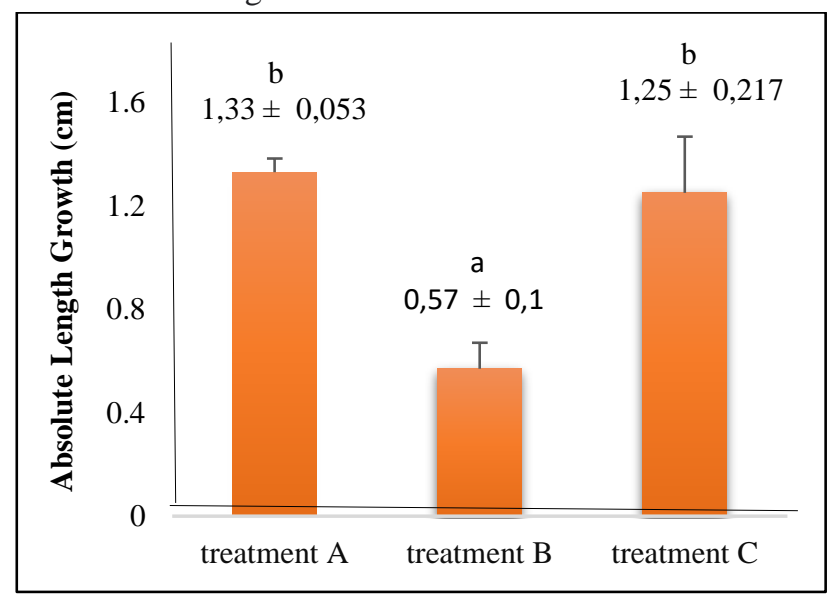

Figure. 2 Absolute Lenght Growth of B. splendens

Noted: Different superscip letters in the image indicated that the treatment is significantly different $(\mathrm{P}<0,05)$ compared to other treatments.

Research data on three treatments showed that the highest absolute length growth was found in treatment $\mathrm{A}$ (silkworms for 6 weeks). This is presumably because silk worms' natural feed is a very good feed to use in the growth of fish seeds. This is following the opinion of Suharyadi [10] which states that Tubifex sp. used for fish seed feed because it has a high enough nutritional content, besides that it is easy to digest, the size is following the fish's mouth opening, the movement is slow and has an odor and color that can stimulate fish to eat it. Giving silkworms is very good for fish growth.
The results that showed the lowest absolute length were in treatment B (pellets for 6 weeks) where the increase in length produced was also the smallest compared to the increase in length produced in treatments A and C. This was presumably because artificial feed had shortcomings given to betta fish, namely artificial feed, has a shape and aroma that is less preferred by Betta fish seeds compared to natural food for silkworms. According to the opinion of Afrianto and Liviawaty [11], fish seeds are not able to digest artificial feed properly and artificial feed has an aroma, appearance, texture, and taste that fish does not like, which causes a decrease in fish appetite.

The results obtained in treatment $\mathrm{C}$, namely the absolute length which was not significantly different from that in treatment $\mathrm{A}$, although the absolute weight was smaller than that in treatment $\mathrm{A}$, it can be taken into consideration in choosing the type of feed for betta fish, namely betta fish seeds can be given combination feed (silkworms for 3 weeks and feed pellets in the fourth week until the end of the study). This is because the length of the fish in ornamental fish species takes precedence over the weight of the fish. According to the opinion of Asniati et al., [5] stated that the parameter that is prioritized in the ornamental fish trade is the length value compared to the weight value.Survival Rate

Based on the results of observations that have been made in the research of betta fish seeds, it shows that the SR value ranges from $95-100 \%$. The highest value of SR generated in treatment A and treatment B was $100 \%$, while the value of SR generated in treatment $\mathrm{C}$ was $95 \%$. The results of the One-Way ANOVA statistical test show that the significance value is smaller than $0.05(\mathrm{P}>0.05)$, which means that all treatments do not have a significant effect on the absolute length growth of betta fish (B. splendens) seeds which can be seen in Figure 3.

The research data on the three treatments indicated that the SR value was good. The highest SR value was in treatment A (silkworms for 6 weeks) and treatment $\mathrm{C}$ (the combination of the two, namely silkworms in the first week to the third week and pellets in the fourth week to the end of the study), while the lowest SR value was in treatment B (pellets), namely $95 \%$.

This is following the opinion of Mulyani et al., [12] which states that there are three categories in determining the survival rate of fish, namely $\mathrm{SR} \geq 50 \%$ which is in the good category, SR $30-50 \%$ is in the moderate category, and if SR $<30 \%$ are classified as the low category (not good). 


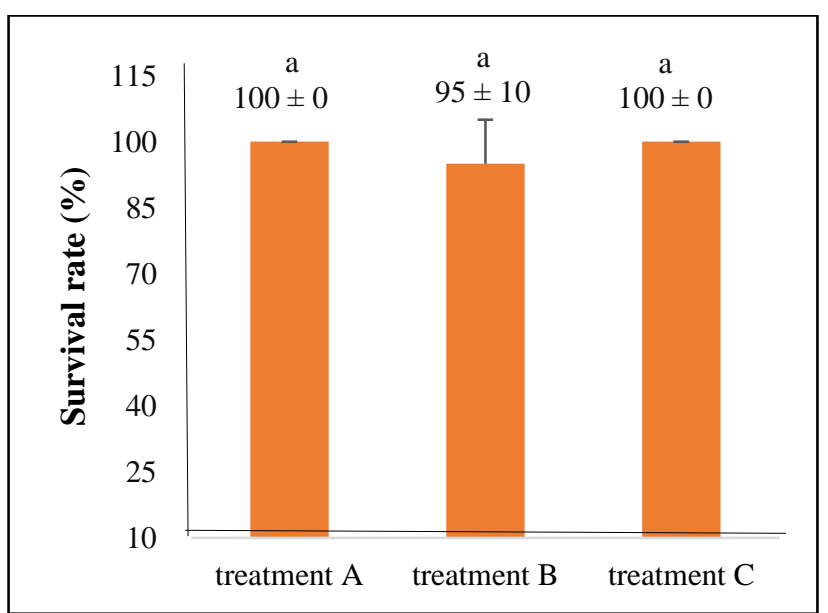

Figure. 3 Survival Rate of B. splendens

Noted: Different superscip letters in the image indicated that the treatment is significantly different $(\mathrm{P}<0,05)$ compared to other treatments.

This is following research conducted by Fernando [13] which states that the average survival (SR) value of betta fish ranges from $87-100 \%$ and is in a good category.

\section{Water Quality}

Based on the results of measurements of water quality parameters in the B. splendens study, it was shown that the temperature values obtained ranged from 25.01 to $25.87^{\circ} \mathrm{C}$. The temperature value shows that all treatments have almost the same value, namely treatment $\mathrm{A}$ obtained $25.87^{\circ} \mathrm{C}$, treatment $\mathrm{B}$ obtained $25.80^{\circ} \mathrm{C}$, and treatment $\mathrm{C}$ obtained $25.01^{\circ} \mathrm{C}$. The DO values obtained ranged from 4.13-4.17 $\mathrm{mg} / \mathrm{L}$, where the highest DO value was found in treatment B of $4.17 \mathrm{mg} / \mathrm{L}$, followed by treatment $\mathrm{C}$ of 4.14 $\mathrm{mg} / \mathrm{L}$, and the lowest value was treatment A of $4.13 \mathrm{mg} / \mathrm{L}$. The $\mathrm{pH}$ value obtained ranged from 8.42-8.47, where the $\mathrm{pH}$ value in all treatments had almost the same value. The highest $\mathrm{pH}$ value was found in treatment A, namely 8.47, followed by treatment $\mathrm{C}$, namely 8.43 , and the lowest $\mathrm{pH}$ value found in treatment $\mathrm{B}$, namely 8.42 as in Table 1 .

TABLE 1 .

AVERAGE WATER QUALITY

\begin{tabular}{|c|c|c|c|c|}
\hline \multirow{2}{*}{ Parameter } & \multicolumn{3}{|c|}{ Treatment } & \multirow{2}{*}{$\begin{array}{l}\text { optimum } \\
\text { value }\end{array}$} \\
\hline & A & B & $\mathrm{C}$ & \\
\hline $\begin{array}{l}\text { Temperature } \\
\left({ }^{\circ} \mathrm{C}\right)\end{array}$ & 25,87 & 25,80 & 25,01 & $\begin{array}{c}24-30^{\circ} \mathrm{C} \\
(\text { Sunari, 2008) } \\
>3 \mathrm{mg} / \mathrm{l}\end{array}$ \\
\hline $\mathrm{DO}(\mathrm{mg} / \mathrm{L})$ & 4,13 & 4,17 & 4,14 & $\begin{array}{c}\text { (Setyowati et } \\
\text { al., 2014) }\end{array}$ \\
\hline $\mathrm{pH}$ & 8,47 & 8,42 & 8,43 & $\begin{array}{c}\text { 7-8,5 } \\
\text { (Yanuar, } \\
\text { 2017) }\end{array}$ \\
\hline
\end{tabular}

The results of water quality measurements during the study showed that all parameters at temperature, DO, and
$\mathrm{pH}$ was following the requirements for freshwater ornamental fish cultivation. The temperature value during the study ranged from $25.0-25.87^{\circ} \mathrm{C}$, this temperature value is suitable for use in fish farming. This is following the opinion of Sunari [14] which states that the optimal temperature used for raising betta fish to support growth is around 24-30.

The DO value (dissolved oxygen) during the study ranged from $4.13-4.7 \mathrm{mg} / \mathrm{L}$, this DO value is suitable for the cultivation of freshwater ornamental fish, this is following the opinion of Setyowati et al., [15] stated that generally good DO is used for the growth of betta fish around $>3$ ppm. According to Fahmi et al., [16] stated that DO shows the amount of dissolved oxygen in water, oxygen is used for respiration and oxidation processes. Betta fish are classified as labyrinth fish, so they have a high tolerance for dissolved oxygen and these fish can survive in an oxygen-poor environment. The $\mathrm{pH}$ value during the study ranged from $8.42-8.47$. This $\mathrm{pH}$ value is good for fish farming, this is following the opinion of Yanuar [17] which states that fish are very sensitive to temperature changes, but fish prefer a neutral $\mathrm{pH}$ ranging from 7-8.5.

\section{CONCLUSION}

The results showed that different feeding had a significant effect on the growth of absolute weight and absolute length where the highest growth was in treatment A, followed by treatment $\mathrm{C}$ and the lowest was in treatment B. Different feeding has no significant effect on the survival rate of betta fish.

\section{ACKNOWLEDGMENT}

I thank the Tugu Mina Asri Marine and Fisheries Independent Training Center, Tulungagung Regency, East Java, who has been willing to provide loans for measuring water quality in the waters during the research.

\section{REFERENCES}

[1] Atmadjaja, J. 2009. Panduan Lengkap Memelihara Cupang Hias dan Cupang Adu. Penebar Swadaya. Jakarta.

[2] Yusuf, A., Koniyo, Y., dan Muharam, A. 2015. Pengaruh Perbedaan Tingkat Pemberian Pakan Jentik Nyamuk terhadap Pertumbuhan Benih Ikan Cupang. Jurnal Nike, 3(3): 106-110.

[3] Anggraeni, N. M., Abdulgani, N. 2013. Pengaruh Pemberian Pakan Alami dan Pakan Buatan Terhadap Pertumbuhan Ikan Betutu (Oxyeleotris marmorata) pada Skala Laboraturium. Jurnal Sains dan Seni ITS, 2(2): 197-201.

[4] Sari, R. Y., N.L. Watiniasih, S.A. Saraswati. 2019. Laju Pertumbuhan Rotifera (Branchionus plicatilis) di 
Media Kultur Berdasarkan Jenis Pakan Kombinasi. Current Trends in Aquatic Science, 2(1): 95-102.

[5] Asniati, W, I.M., \& Wardoyo, S. E. 2013. Kajian Berbagai Jenis Pakan Terhadap Pertumbuhan Benih Ikan Cupang Bagan (Betta imbellis var. Sumatraensis). Jurnal Sains Natural Universitas Bangsa, 3(1): 85-100.

[6] Effendie. 1997. Metode Biologi Ikan. Bogor: Yayasan Dwi Sri. Hal 112.

[7] Suryanti, Y., \& Priyadi, A. 2002. Penentuan Saat Awal Pemberian Pakan Buatan Dan Hubungannya dengan Perkembangan Aktivitas Enzim Pencernaan pada Benih Ikan Baung (Mystus nemurus C.V.). Jurnal Penelitian Perikanan Indonesia, 8(5): 37-42.

[8] Trisnawati, Y., Suminto, \& Sudaryono, A. 2014. Pengaruh Kombinasi Pakan Buatan Cacing Tanah (Lumbricus rubellus) Terhadap Efisiensi Pemanfaatan Pakan, Pertumbuhan Dan Kelulushidupan Lele Dumbo (Clarias gariephinus). Journal of Aquaculture Management and Technology, 3(2): 89-93.

[9] Kaseger, M.J., Pangkey, H., Kusen, D. J., Manoppo, H., Mingkid, W. M., \& Bataragoa, N. E. 2019. Pemanfaatan Pakan Alami Alona sp., Rebusan Kuning Telur dan Pakan Komersial Terhadap Peningkatan Kelangsungan Hidup Larva Ikan Cupang. Jurnal Ilmiah Patax, 7(2): 335-340.

[10] Suharyadi. 2012. Studi Penumbuhan dan Produksi Cacing Sutra (Tubifex sp.) dengan Pupuk yang
Berbeda dalam Sistem Resirkulasi. [Thesis]. Universitas Terbuka. $116 \mathrm{hlm}$.

[11] Afrianto, E., dan E. Liviawaty. 2005. Pakan Ikan. Kanasius.Yogyakarta.

[12] Mulyani. 2014. Pengaruh Pemberian Papain Terhadap Tingkat Pemanfataan Protein Pakan dan Pertumbuhan Lele Dumbo. Jurnal Akuakultur Rawa Indonesia, 2(1): 01-12.

[13] Fernando, R. 2019. Pengaruh Penambahan Tepung Wortel (Daucus Carota) Pada Pakan Buatan Terhadap Peningkatan Kecerahan Warna Ikan Cupang (Betta splendens Regan). [Skripsi]. Fakultas Perikanan dan Ilmu Kelautan, Universitas Muhammadiyah Ponttianak. 66 hlm.

[14] Sunari. 2008. Budidaya Ikan Cupang. Ganeca Exact. Bekasi. 106 hal.

[15] Setyowati, RR. I., Naswati, W., Heatiningsih, Miftakhodin, Cahyadi, Ayu D. 2014. Prakarya dan Kewirausahaan. Jakarta: Pusat Kurikulum dan Perbukuan, Balitbang, Kemdikbud.

[16] Fahmi, R.M., Ginanjar, R. \& Kusumah, R.V. 2015. Keragaman Ikan Hias di Lahan Gambut Cagar Biosfer Bukit-Batu, Provinsi Riau. Prosiding Seminar Naasional Masyarakat Biodiversitas Indonesia, 1(1): 51-58.

[17] Yanuar, V. 2017. Pengaruh Pemberian Jenis Pakan yang Berbeda Terhadap Laju Pertumbuhan Benih Ikan Nila (Oreochromis niloticus) dan Kualitas Air di Akuarium Pemeliharaan. ZIRAA'FAH, 42(2): 91-99. 